\title{
Early NFkB Activation Is Inhibited During Focal Cerebral Ischemia in Interleukin-1及- Converting Enzyme Deficient Mice
}

\author{
Feng-Peng Huang, ${ }^{1,4}$ Zhi-Qiu Wang, ${ }^{1,4}$ Du-Chu Wu, ${ }^{1}$ Gerald P. Schielke, ${ }^{1,3}$ Yi Sun, ${ }^{2}$ \\ and Guo-Yuan Yang ${ }^{1 \star}$ \\ ${ }^{1}$ Department of Surgery (Neurosurgery), University of Michigan, Ann Arbor \\ ${ }^{2}$ Department of Molecular Biology, Pfizer Global Research and Development, Ann Arbor, Michigan \\ ${ }^{3}$ Department of CNS pharmacology, Pfizer Global Research and Development, Ann Arbor, Michigan \\ ${ }^{4}$ Department of Neurosurgery, Institute of Neurology, Hua-Shan Hospital, Shanghai Medical School, \\ Fudan University, Shanghai, China
}

Our previous study demonstrated that the inhibition of interleukin-1 $\beta$ (IL-1 $\beta$ ) reduces ischemic brain injury; however, the molecular mechanism of the action of IL-1 in cerebral ischemia is unclear. We are investigating currently the role of $\mathrm{NF \kappa B}$ during focal cerebral ischemia, using mutant mice deficient in the interleukin-1 converting enzyme gene (ICE KO) in a middle cerebral artery occlusion (MCAO) model. Adult male ICE KO and wildtype mice $(n=120)$ underwent up to $24 \mathrm{hr}$ of permanent MCAO. Cytoplasmic phospho-NFKB/p65 expression in ischemic brain was examined using Western blot analysis and immunohistochemistry. NFKB DNA-binding activity was detected using electrophoretic mobility shift assay (EMSA). Furthermore, ICAM-1 expression was examined in both the ICE KO and wild-type mice (WT). Western blot analysis and immunostaining showed that the level of cytosolic phosphorylated NFKB/p65 increased after 2 and $4 \mathrm{hr}$ of MCAO in WT mice; however, $\mathrm{NF} \kappa \mathrm{B} / \mathrm{p} 65$ was significantly reduced after MCAO in the ICE KO mice $(P<0.05)$. EMSA showed that NFKB DNAbinding activity increased after MCAO in WT mice; but this effect was reduced in the ICE KO mice. The number of ICAM-1-positive vessels in the ischemic hemisphere was greatly attenuated in the ICE KO mice $(P<0.05)$, which paralleled the results of immunohistochemistry. Our results demonstrate that $N F_{\kappa} B$ phosphorylation is reduced in ICE KO mice, suggesting that ICE or IL-1 are involved in early NFKB phosphorylation. Because cerebral ischemia induced infarction is significantly reduced in ICE KO mice, we conclude that early NFKB phosphorylation plays a disruptive role in the ischemic process. ๑ 2003 Wiley-Liss, Inc.

Key words: intercellular adhesion molecule-1 (ICAM-1); interleukin-1 $\beta$ (IL-1 $\beta$ ); IL-1 $\beta$-converting enzyme (ICE); middle cerebral artery occlusion; nuclear factor kappa $B$ (NFKB)

Cerebral ischemia activates a cascade of intracellular signal transduction pathways through the production of many different stimuli, including proinflammatory cytokines, reactive oxygen species (ROS), neurotrophic factors, and calcium influx (Mattson, 1997). It is well known that proinflammatory cytokines play an important role in the pathogenesis of cerebral ischemia (Dinarello, 1997b). Interleukin-1 $\beta$ (IL-1 $\beta$ ), a proinflammatory cytokine, is increased markedly during global and focal cerebral ischemia and postischemic reperfusion (Rothwell and Hopkins, 1995; Szaflarski et al., 1995; Arvin et al., 1996). Exogenous application of IL-1 $\beta$ exacerbates ischemic brain injury, whereas administration or overexpression of IL-1 receptor antagonist (IL-1ra) greatly reduces ischemic brain injury (Minami et al., 1992; Yamasaki et al., 1992, 1996; Betz et al., 1995; Loddick and Rothwell, 1996; Feuerstein et al., 1997). IL-1 $\beta$-converting enzyme (ICE) cleaves inactive $31-\mathrm{kD}$ pro-IL-1 $\beta$ to the active $17-\mathrm{kD}$ IL-1 $\beta$ form and processes the pro-interferon $\gamma$-inducing factor. ICE is a member of a family of cysteine proteases, the caspases, several of which are associated with the apoptotic cell death pathway. This pathway has been implicated in ischemic brain damage (Linnik et al., 1993). Our previous studies have demonstrated that ischemic brain injury, edema formation, and inflammatory responses were reduced significantly in ICE knockout (ICE KO) mice (Schielke et al., 1998; Yang et al., 1999c). It is uncertain, however, whether ICE-deficient mice are protected from ischemic damage by a reduction of inflammatory response, apoptosis, or both (Hara et al., 1997b; Schielke et al., 1998).

Contract grant sponsor: NIH; Contract grant number: R01 NS-35089.

${ }^{\star}$ Correspondence to: Guo-Yuan Yang, MD, PhD, Departments of Anesthesia and Neurosurgery, Center for Cerebrovascular Research, San Francisco General Hospital, UCSF, Room 3C-38, 1001 Potrero Ave., San Francisco, CA 94110. E-mail: gyyang@anesthesia.ucsf.edu

Received 27 February 2003; Revised 26 March 2003; Accepted 31 March 2003

(C) 2003 Wiley-Liss, Inc. 
Responses to a variety of stimuli associated with stress and injury such as ischemia are mediated through numerous intracellular signaling molecules(Carroll et al., 2000). An important signaling molecule among them is nuclear transcription factor kappa $\mathrm{B}(\mathrm{NF \kappa B})$, which is activated by cytokines, mitogens, physical or oxidative stress, and chemical agents (Siebenlist et al., 1994). Potent inducers of $\mathrm{NF \kappa B}$ include cytokines, tumor necrosis factor-alpha (TNF $\alpha)$, IL-1 $\beta$, lipopolysaccharide, oxygen free radicals, ultraviolet light, and $\gamma$-irradiation (Baeuerle and Baichwal, 1997). NFKB is classified as a Rel protein and is distinguished structurally by a Rel homology domain that is involved in DNA binding and dimerization (Verma et al., 1995). NFKB is composed normally of a dimer of $50-$ and $65-\mathrm{kD}$ subunits that reside in the cytoplasm of most cells and are bound to an inhibitory protein, I kappa B (IкB). Upon exposure to stimuli, ІкB protein is phosphorylated, followed by ubiquitination and degradation. As a consequence, NFKB is phosphorylated and translocated into the nucleus, where it initiates gene transcription. It is known that phospho-NFKB participates in the control of transcription of over 150 target genes, including proinflammatory cytokines, chemokines, immunoreceptors, acute phase proteins, stress response genes, and regulators of apoptosis (Gilmore et al., 1996; Gilmore, 1997).

To identify the relationship between decreased levels of ICE and the phosphorylation of NFKB, we designed the present experiments to determine the levels of phospho-NFкB after middle cerebral artery occlusion (MCAO) in mutant mice deficient in the ICE gene. Furthermore, we examined the role of NFKB in regulating the inflammatory response during focal cerebral ischemia.

\section{MATERIALS AND METHODS}

\section{Animal Preparation}

The institutional animal care and use committee approved the procedures for the use of laboratory animals. The ICE KO mice were developed and characterized by the BASF Corporation, (Worcester, MA) (Li et al., 1995). These mice contain a null mutation in the ICE gene (ICE-/-) generated by homologous recombination in embryonic stem cells. The wild-type (WT, ICE+/+) mice were generated from the same chimeric founder, and interbred amongst themselves. Both strains have a mixed background of SV129- and C57BL/6-derived genes.

\section{Experimental Groups}

Three separate paradigms were used in this study. The first experiment measured the time course of NFKB expression after MCAO using Western blot analysis. Adult ICE KO $(n=20)$ and WT mice $(n=20)$ weighing $28-35 \mathrm{~g}$ underwent $0.5,2,4$, 8 , and $24 \mathrm{hr}$ of permanent MCAO ( $n=4$ at each point). The second experiment localized NFкB and intercellular adhesion molecule-1 (ICAM-1) expression using double-labeled fluorescence staining or stable 3,3'-diaminobenzidine tetrahydrochloride (DAB; Research Genetics, Huntsville, AL) immunostaining. ICE KO $(n=20)$ and WT mice $(n=20)$ underwent 0,2 , 4,8 , and $24 \mathrm{hr}$ of permanent MCAO ( $n=4$ at each time point).
The third experiment examined the NFKB activity using electrophoretic mobility gel-shift assay (EMSA). The time points and animal numbers were the same as Experiment 1 and 2.

\section{Middle Cerebral Artery Occlusion}

Adult ICE KO and WT mice were anesthetized with $4 \%$ isoflurane in $70 \% \mathrm{~N}_{2} \mathrm{O} / 30 \% \mathrm{O}_{2}$ and maintained with $1.5 \%$ isoflurane through a facemask. Body temperature was maintained with a heated blanket using a feedback control system (73A, Yellow Springs, Ohio). MCAO was carried out as described previously (Yang et al., 1994). Briefly, the left common carotid artery was exposed through a midline incision. The internal carotid artery was isolated and the pterygopalatine branch ligated close to its origin. A 2-cm length of 5-0 rounded tip nylon suture was gently advanced from the external carotid artery through the common carotid artery and into the internal carotid artery for a distance of $11.0 \pm 0.5 \mathrm{~mm}$.

\section{Surface Cerebral Blood Flow Measurement}

Surface cerebral blood flow (sCBF) was measured using a laser-Doppler flowmetry monitor (Model BPM2 System; Vasamedics, St. Paul, MN) equipped with a small caliber probe of $0.7-\mathrm{mm}$ diameter (P-433; Vasamedics). Surface CBF was measured 5 min before and $15 \mathrm{~min}$ after MCAO at three points: 1) the ischemic core: $3.5 \mathrm{~mm}$ lateral and $1 \mathrm{~mm}$ posterior to the bregma on the ipsilateral hemisphere; 2) the control area: corresponding site on the contralateral hemisphere; and 3) the perifocal area: $1 \mathrm{~mm}$ lateral and $1 \mathrm{~mm}$ posterior to the bregma on the ipsilateral hemisphere. Blood flow values are expressed as a percentage of baseline values (Yang et al., 1997).

\section{Western Blot Analysis}

Mice were sacrificed at $0.5,2,4,8$, and $24 \mathrm{hr}$ of MCAO. The brains were removed immediately and divided into contralateral and ipsilateral hemispheres. Tissue samples were homogenized and lysed in a buffer containing $150 \mathrm{mM} \mathrm{NaCl}$, $50 \mathrm{mM}$ Tris-Cl, $1 \% \mathrm{NP}-40,0.5 \%$ DOC, $0.1 \%$ sodium dodecyl sulfate (SDS), and $100 \mu \mathrm{g} / \mathrm{ml}$ polymethylsulfonylfluoride, as well as $2 \mu \mathrm{g} / \mathrm{ml}$ each of pepstatin, leupeptin, and chymostatin. Lysates were cleared by centrifugation at $14,000 \times g$ for $10 \mathrm{~min}$ at $4^{\circ} \mathrm{C}$. The protein concentration of each sample was determined with a Bio-Rad assay (Bio-Rad, Hercules, CA). Western blot analysis was carried out using standard techniques (Sambrook et al., 1989). The sample was boiled at $100^{\circ} \mathrm{C}$ in SDS gel loading buffer $(100 \mathrm{mM}$ Tris-Cl, 4\% SDS, $0.2 \%$ bromophenol blue, and $20 \%$ glycerol) for $5 \mathrm{~min}$. The protein sample was loaded onto a 7.5\% SDS polyacrylamide gel. After electrophoresis, size-fractionated proteins were electrotransferred to a polyvinylidene difluoride membrane (PVDF; Bio-Rad Laboratories, Hercules, CA) in a transfer buffer. The membrane was placed in $5 \%$ powdered milk in $100 \mathrm{mM}$ phosphate-buffered saline (PBS) solution with $0.1 \%$ Tween 20 (PBST) for $60 \mathrm{~min}$ at room temperature to block nonspecific binding. The transferred PVDF membrane was probed with polyclonal goat anti-activate NFкB/p65 antibody (1:500 dilution; Santa Cruz Biotechnology, Santa Cruz, CA) in blocking buffer overnight at $4^{\circ} \mathrm{C}$. After washing, the membrane was immunoprobed with peroxidaseconjugated anti-goat IgG-HRP (1:2,000 dilution; Santa Cruz Biotechnology). An enhanced ECL kit (Amersham, Bucking- 
hamshire, UK) was applied to detect the active NFKB protein according to the manufacturer's instructions. Protein amount was quantified by a gel densitometric scanning program using NIH 1.62 image software.

\section{Immunohistochemistry}

ICE KO and WT mice were anesthetized and perfused transcardially with heparinized saline, followed by $2 \%$ paraformaldehyde in $100 \mathrm{mM}$ PBS, pH 7.4 (Sigma, St. Louis, MO), after $0.5,2,4,8$, and $24 \mathrm{hr}$ of MCAO. Brains were removed, postfixed overnight in the same solution, immersed in $25 \%$ sucrose at $4^{\circ} \mathrm{C}$ until they sunk to the bottom, and then embedded in a 60\%/40\% sucrose/OCT (Sakura Finetek, Torrance, CA) solution. Coronal sections (20 $\mu \mathrm{m}$ in thickness) were cut on a cryostat (CM1800; Leica, Germany) and mounted on precleaned microscope slides (Fisher Scientific, Pittsburgh, PA). For single $\mathrm{NF \kappa B} / \mathrm{p} 65$ immunohistochemistry, sections were incubated for $30 \mathrm{~min}$ with $10 \%$ goat serum to reduce nonspecific binding. Sections were then washed in PBST (PBS containing $0.5 \%$ Triton $\mathrm{X}-100)$ and incubated overnight at $4{ }^{\circ} \mathrm{C}$ with a rabbit polyclonal anti-active NFKB/p65 antibody (1:500 dilution; Santa Cruz Biotechnology). Negative controls were carried out using the same concentration of normal rabbit IgG instead of primary antibody. After treatment with $1 \% \mathrm{H}_{2} \mathrm{O}_{2}$ in $30 \% / 70 \%$ methanol/PBS solution, the sections were incubated with a biotinylated goat anti-rabbit secondary antibody in 1:200 dilution for $90 \mathrm{~min}$ at room temperature, followed by an $\mathrm{ABC}$ process (ABC-Elite Kit; Vector, San Francisco, CA). Finally, the sections were treated with stable 3,3'-diaminobenzidine tetrahydrochloride (DAB, Research Genetics, Huntsville, AL) as a peroxidase substrate and counterstained with hematoxylin. ICAM-1 expression was carried out as described above except the first antibody was rabbit polyclonal anti-ICAM-1 antibody (Caltag, San Francisco, CA). The total numbers of deep brownstained positive vessels were counted in each hemisphere, including the cortex and basal ganglia region. ICAM-1 vessel counting was done manually to exclude the infiltrating cells occasionally expressing ICAM-1.

When double-labeled fluorescent immunohistochemistry was used, sections were incubated for $30 \mathrm{~min}$ with 10\% donkey serum to reduce nonspecific binding, then incubated overnight at $4^{\circ} \mathrm{C}$ with the goat anti-active NFkB/p65 antibody (1:200 dilution; Santa Cruz Biotechnology). After washing, fluorescein-conjugated donkey anti-goat $\operatorname{IgG}$ (1:100 dilution; Vector) was applied for $60 \mathrm{~min}$ at room temperature. Sections were incubated with polyclonal rabbit anti-neuron specific enolase (NSE, 1:200 dilution; Chemicon International, Temecula, CA) antibody for $2 \mathrm{hr}$ at room temperature. NSE immunoreactivity was detected using rhodamine-conjugated donkey antirabbit IgG (1:100 dilution; Vector Laboratories, Burlingame, CA) at room temperature. Double-labeled immunostaining was evaluated using a fluorescence microscope (Nikon MicrophotoSA) with a filter cube (excitation filter, 450-490 nm; suppression filter, $515-560 \mathrm{~nm}$ ) for fluorescein isothiocyanate labeling and another filter cube (excitation filter, 515-560 nm; suppression filter, $590 \mathrm{~nm}$ ) for rhodamine. Photomicrographs for double labeling illustrations were obtained by changing the filter cube without altering the position or focus of the section (Gong et al., 1998).

\section{Nuclear Extraction and Electrophoretic Mobility Shift Assay}

The nuclear extraction and electrophoretic mobility shift assay (EMSA) was carried out as specified by the manufacturer's instructions (Promega, Minneapolis, MN). After the animals were sacrificed, the brains were removed immediately and homogenized in a microfuge tube with buffer A (10 mM HEPES, $\mathrm{pH} 7.9,10 \mathrm{mM} \mathrm{KCl}, 1.5 \mathrm{mM} \mathrm{MgCl}_{2}, 0.5 \mathrm{mM}$ dithiothreitol [DTT], $1 \mathrm{mM}$ AEBSF, and $10 \mu \mathrm{g} / \mathrm{ml}$ leupeptin). The nuclei were collected by centrifugation at $500 \times g$ for $10 \mathrm{~min}$ and washed once with buffer A containing $0.2 \% \mathrm{NP}-40$. The nuclear proteins were then extracted with buffer B $(20 \mathrm{mM}$ HEPES, pH 7.9, $0.42 \mathrm{mM} \mathrm{NaCl}, 20 \%$ glycerol, $1 \mathrm{mM}$ EDTA, $1 \mathrm{mM}$ DTT, $1 \mathrm{mM}$ AEBSF, and $10 \mu \mathrm{g} / \mathrm{ml}$ leupeptin) for $30 \mathrm{~min}$ at $4^{\circ} \mathrm{C}$, and microfuged for $30 \mathrm{~min}$. The nuclear extracts were microdialyzed against buffer C (20 mM HEPES, pH 7.9, $20 \%$ glycerol, $100 \mathrm{mM} \mathrm{KCl,} 0.2 \mathrm{mM}$ EDTA, $0.5 \mathrm{mM}$ DTT, $0.5 \mathrm{mM}$ AEBSF) with an ultrafree centrifugal filter (Millipore) and frozen at $-80^{\circ} \mathrm{C}$. For determination of protein-DNA interactions, a double-stranded oligonucleotide containing NFкB consensus binding sequence (5'-AGT TGA GGG GAC TTT CCC AGG C-3') was used (Promega) and end-labeled with gamma $\left[{ }^{32} \mathrm{P}\right]-\mathrm{ATP}$ according to manufacturer's recommendation. The NFKB binding reactions were carried out in a final volume of $20 \mu \mathrm{l}$ mixtures containing buffer $(10 \mathrm{mM}$ HEPES, $\mathrm{pH} 7.5,0.25 \mu \mathrm{g} / \mu \mathrm{l}$ poly $[\mathrm{dI} / \mathrm{dC}], 0.1 \mathrm{mM} \mathrm{NaCl}, 0.8 \mathrm{mM}$ EDTA, 1 mM DTT, 0.05\% NP-40, 4\% glycerol), $10 \mu \mathrm{g}$ nuclear proteins, and $10^{6} \mathrm{cpm}$ of radiolabeled probe. The mixtures were incubated for $20 \mathrm{~min}$ at room temperature. The DNA-protein complexes were resolved on a $5 \%$ nondenaturing polyacrylamide gel in $0.5 \times$ Tris-borate/EDTA buffer. The gel was dried and exposed to Kodak X-ray film overnight at $-70^{\circ} \mathrm{C}$. EMSA was carried out on nuclear extracts from each sample after ischemia. Semiquantitation of the EMSA was carried out with densitometry.

\section{Statistical Analysis}

Microcomputer based statistical programs (Statview II; ABACUS, Berkeley, CA and Excel; Microsoft, Redmond, WA) were used. All data are presented as mean \pm SD. Parametric data at different points during MCAO between the ICE $\mathrm{KO}$ and the WT mice were compared using ANOVA followed by Student's $t$-test. A probability value of $<5 \%$ was considered significant.

\section{RESULTS}

\section{Physiological Parameters}

ICE KO and WT mice developed normally with no visible neurological deficit detected in either group. The blood pressure, blood gases, and body temperature changes were similar and there were no statistical differences between the ICE KO and the WT mice at 0.5, 2, 4, 8 , and $24 \mathrm{hr}$ after MCAO (data not shown). Surface CBF dropped sharply to below $20 \%$ of baseline in the ischemic core, and to $35-50 \%$ of baseline in the ipsilateral perifocal region. $\mathrm{CBF}$ was maintained at approximately $100 \%$ of baseline in the contralateral hemisphere after MCAO in both ICE KO and WT mice. There were no statistical 

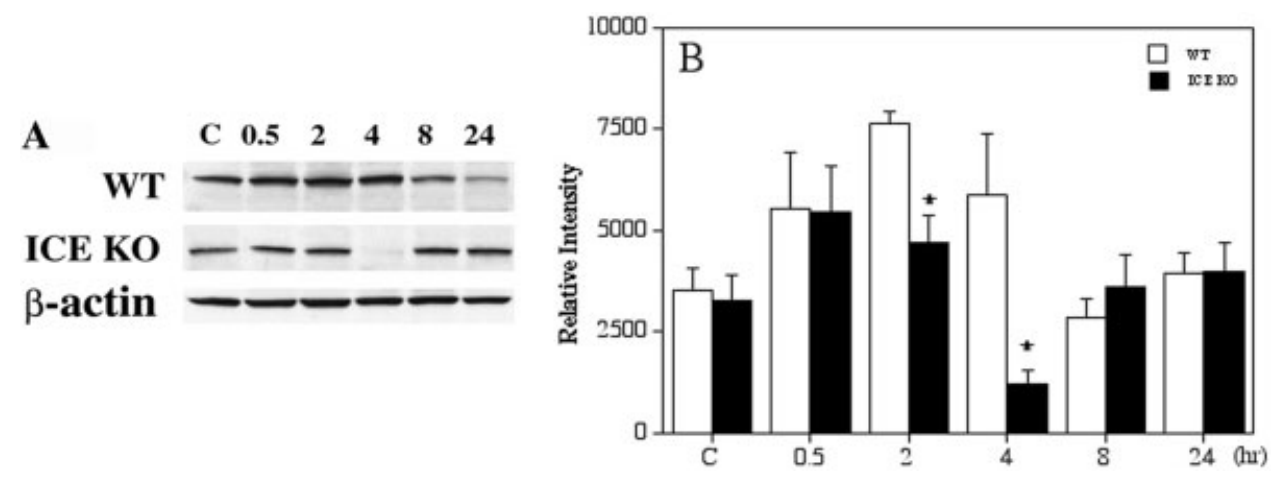

Fig. 1. Increase of $\mathrm{p} 65 / \mathrm{NF \kappa B}$ activation in mouse brain after ischemia. A: Activated p65/NFkB expression during ischemia in WT and ICE KO mouse brain. Cytoplasmic protein extracts were prepared from the ischemic hemisphere in mouse brain after $0.5,2,4,8$, and $24 \mathrm{hr}$ of MCAO; shows a $65-\mathrm{kD}$ active NFKB band detected by Western blot analysis with a polyclonal anti-active p65/NFKB antibody in a representative experiment. C, sham control animals. An equal amount of extract protein was used in each sample (see $\beta$-actin). B: The bar graph shows densitometric quantity of the p65/NFKB induction during cerebral ischemia in ICE KO and WT mice. C, sham control animals. Values are mean $\pm \mathrm{SD} ; n=4$ for each time. ${ }^{\star} P<0.01$, relative density of activated $\mathrm{p} 65 / \mathrm{NF \kappa B}$ in ICE KO mice vs. that in WT mice.

differences between the two groups $(P>0.05$, data not shown).

\section{Phospho-P65/NFkB Is Decreased in ICE KO Mice After Ischemia}

The levels of phospho-p65/NFKB were measured using Western blot analysis in mouse brain samples collected from both ICE KO and WT mice that underwent $0.5,2,4,8$, and $24 \mathrm{hr}$ of MCAO. Phospho-p65/NFкB was expressed at a very low level in the sham animals or in the contralateral hemisphere of mouse brain after MCAO (data not shown). The phospho-p65/NFkB expression in the ischemic hemisphere, however, shown as a major band at approximately $65 \mathrm{kDa}$, increased as early as $0.5 \mathrm{hr}$ of MCAO, peaked at 2 and $4 \mathrm{hr}$, and then decreased gradually in the WT mice (Fig. 1A, as a representative experiment). Interestingly, phospho-p65/NFKB expression was reduced significantly in ICE KO mice after 2 and $4 \mathrm{hr}$ of MCAO compared to WT mice $(P<0.05)$. Densitometric quantitative data ( $n=4$ at each time) is shown in Figure 1B. Phospho-p65/NFkB expression was reduced significantly after 2 and $4 \mathrm{hr}$ of MCAO in ICE KO mice, demonstrating that ICE or IL-1 is critical to the process of phosphorylation of NFKB during cerebral ischemia.

\section{Cellular Localization of Phospho-p65/NFkB}

Localization of phospho-p65/NFkB during ischemia was assessed by immunostaining brain sections prepared from both the ICE KO and the WT mice that underwent MCAO for different lengths of time. As shown in Figure 2, few phospho-p65/NFkB-positive cells could be detected in brain sections from sham-operated mice or in the contralateral hemisphere in ischemic mice (Fig. 2A,F). Phospho-p65/NFkB-positive cells could be detected, however, in both the ischemic cortex and the caudate putamen after $2 \mathrm{hr}$ of MCAO (Fig. 2C,H). The regions of p65/NFkB-positive cells extended to the perifocal region at $4 \mathrm{hr}$ of MCAO (Fig. 2E,J) in the WT mice. These results correlated with the result from Western blot analysis. The increase of phospho-p65/NFkB immunoreactivity was greatly attenuated, however, in both the ischemic cortex and the caudate putamen in ICE KO mice ( $2 \mathrm{hr}$ of MCAO: Fig. 2A,G; $4 \mathrm{hr}$ of MCAO: Fig.2D,I). No immunoreactivity was detected in the negative control sections (data not shown). Further study showed that the phospho-p65/NFkB was located mainly in cytoplasm after $2 \mathrm{hr}$ of MCAO (Fig. 3C), and translocated into the nucleus after $4 \mathrm{hr}$ of MCAO (Fig. 3D). Double-labeled immunohistochemical studies revealed that early expression of p65/NFKB was colocalized with NSE, a neuron specific marker (Fig. 4). Phospho-p65/NFkB-positive cells appeared in both the ischemic cortex and the caudate putamen after $2 \mathrm{hr}$ of MCAO in WT mice. These results demonstrate that $\mathrm{p} 65 / \mathrm{NF \kappa B}$ was phosphorylated during the early acute ischemic period and early phospho-p65/ $\mathrm{NF \kappa B}$ expression was detected mainly in the neurons.

\section{NFкB DNA Binding Activity}

After release from $\mathrm{I} \kappa \mathrm{B}, \mathrm{NF} \kappa \mathrm{B}$ translocates into the nucleus when it binds to its consensus sequence and transactivates target genes. We next examined NFкB DNAbinding activity by EMSA using samples from the ischemic brain tissue in both the ICE KO and the WT mice. Relative intensities of protein-DNA complex increased after $4 \mathrm{hr}$ of MCAO and remained elevated during $24 \mathrm{hr}$ of MCAO in the WT mice (Fig. 5). This correlates with the immunostaining data showing $\mathrm{p} 65 / \mathrm{NF} \mathrm{B}$ translocation into the nucleus; however, there is no significant induction of NFKB DNA binding after $4 \mathrm{hr}$ of MCAO in ICE KO mice $(P<0.05$, Fig. 5). This data indicates that 


\section{ICE KO WT}
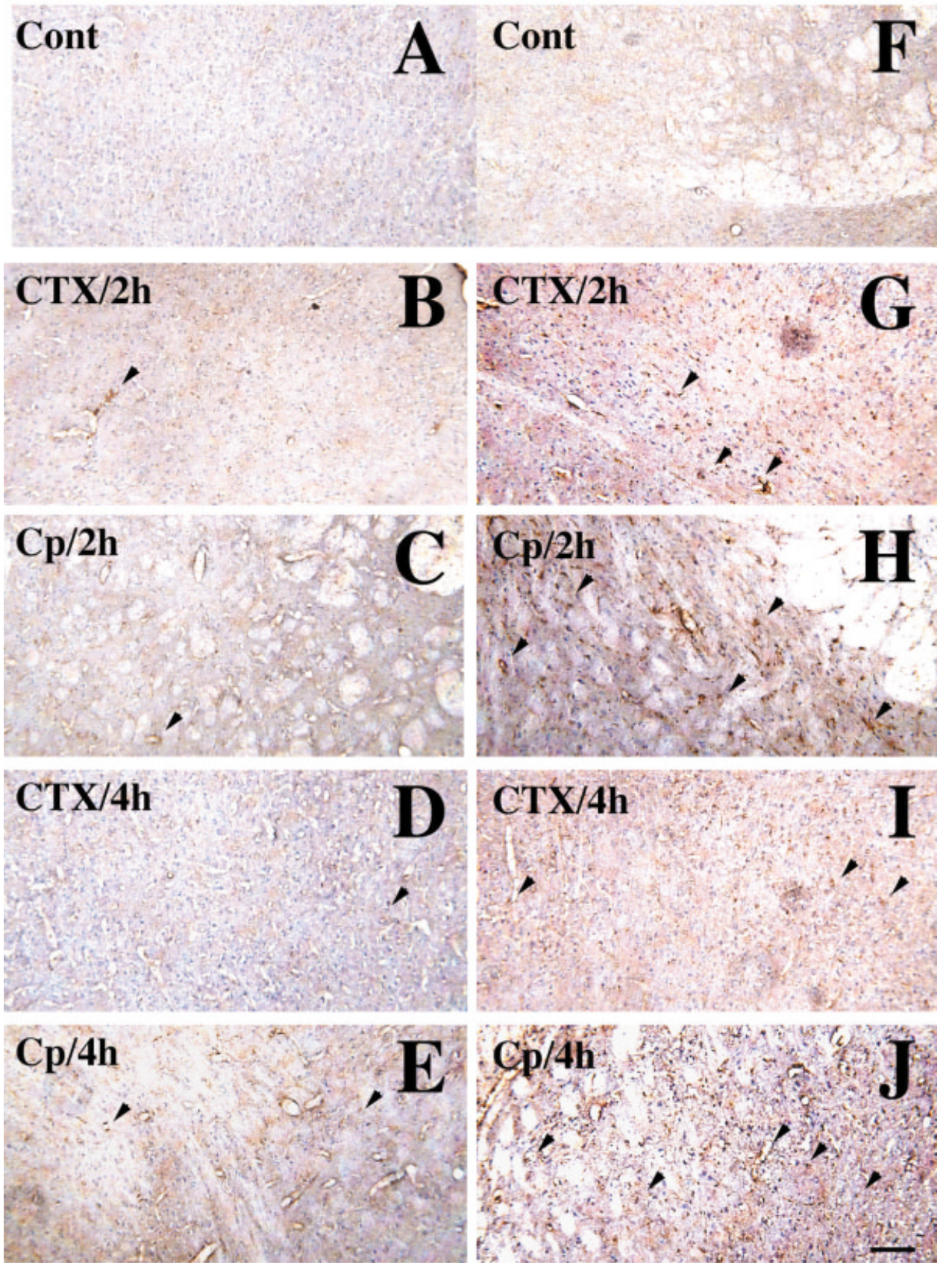

Fig. 2. Localization of $\mathrm{p} 65 / \mathrm{NF \kappa B}$ activation in mouse brain after ischemia. Photomicrographs showed that active p65/NFKB-positive staining in the ICK KO (left column) and the WT mice (right column) after $2(\mathbf{B}, \mathbf{C}, \mathbf{G}, \mathbf{H})$ and $4 \mathrm{hr}(\mathbf{D}, \mathbf{E}, \mathbf{I} \mathbf{~ J})$ of MCAO in the ischemic cortex $(\mathrm{B}, \mathrm{D}, \mathrm{G}, \mathrm{I})$ and caudate putamen (C,E,H,J), respectively. Cont, negative control section (blocking peptide): showed no positive staining in either the ischemic cortex or caudate putamen. CTX, cortex; Cp, caudate putamen; 2h, $2 \mathrm{hr}$ of MCAO; $4 \mathrm{~h}, 4 \mathrm{hr}$ of MCAO. Arrowheads indicate these dark brown cells are phospho-p65/NFkB-positive cells. Many phospho-p65/NFkB-positive cells in both cortex and caudate putamen regions were detected in WT mice after 2 and $4 \mathrm{hr}$ of MCAO; however, ischemia-induced $\mathrm{p} 65 / \mathrm{NF \kappa B}$ phosphorylation was greatly attenuated in ICE KO mice at the same points. Scale bar $=100 \mu \mathrm{m}$. 


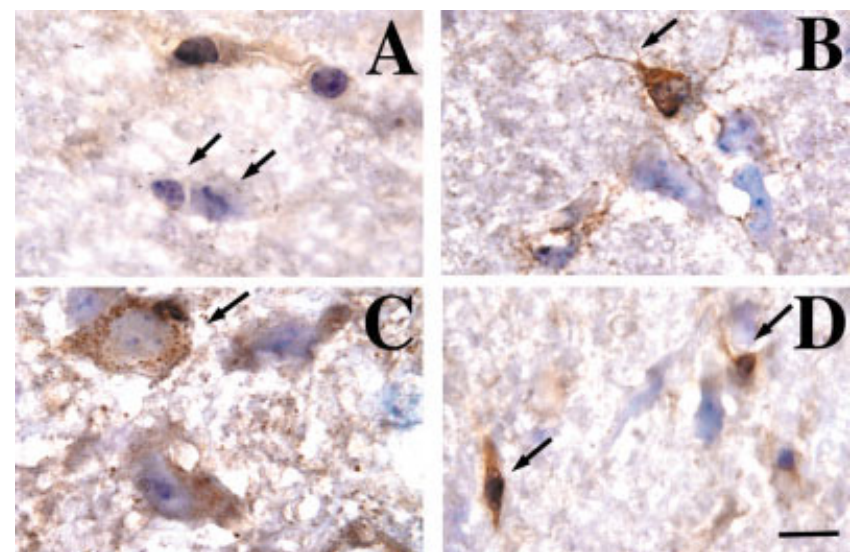

Figure 3 .
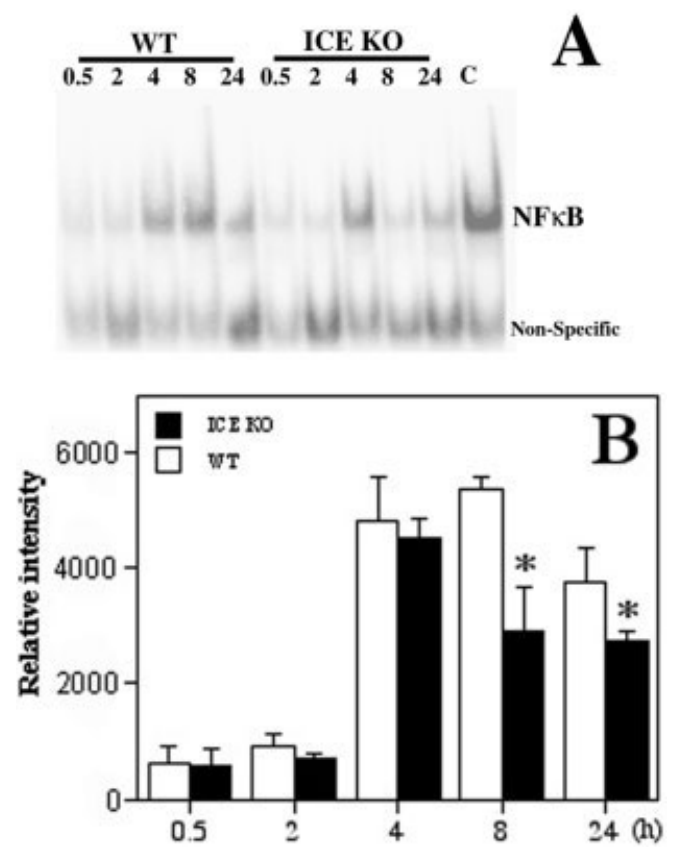

Figure 5.

NFкB was phosphorylated after cerebral ischemia in WT mice, but this ischemia-induced NFKB phosphorylation was inhibited significantly in the ICE-deficient mice.

\section{ICAM-1 Immunostaining}

One known NFкB target gene involved in inflammatory regulation is ICAM-1. Therefore, we examined the expression of ICAM-1 in WT and ICE KO mice. Results showed that ICAM-1-positive vessels in the ipsilateral hemisphere of ICE KO mice were fewer than those in the WT mice after $24 \mathrm{hr}$ of $\mathrm{MCAO}(148 \pm 29 \mathrm{vs}$. $247 \pm 25 ; P<0.05)$. As shown in Figure 6, ICAM-1 expression in the ischemic hemisphere after $24 \mathrm{hr}$ of MCAO was increased in the WT mice; however, the increase of ICAM-1-positive vessels in the ICE KO mice
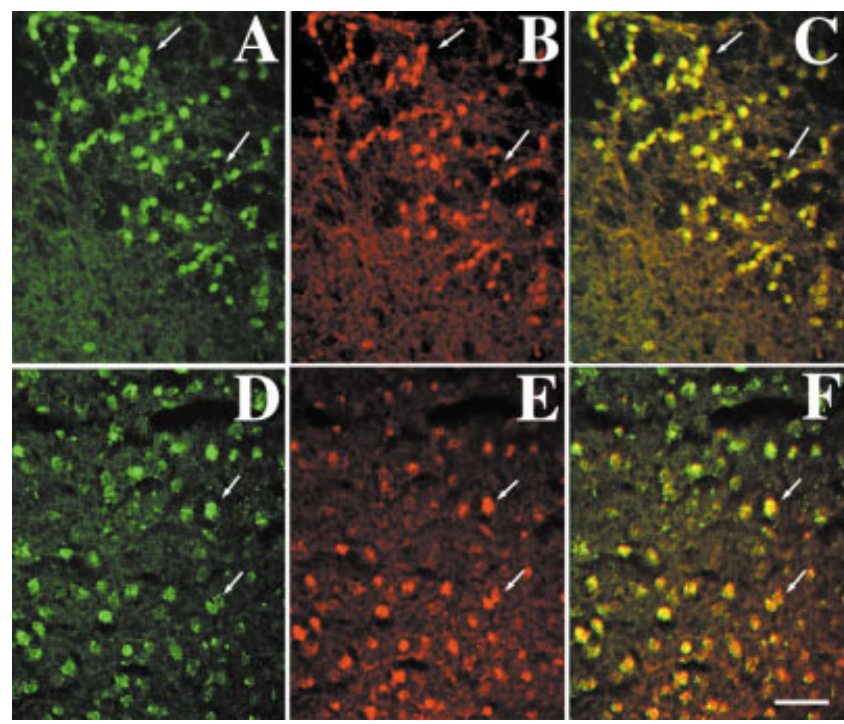

Figure 4

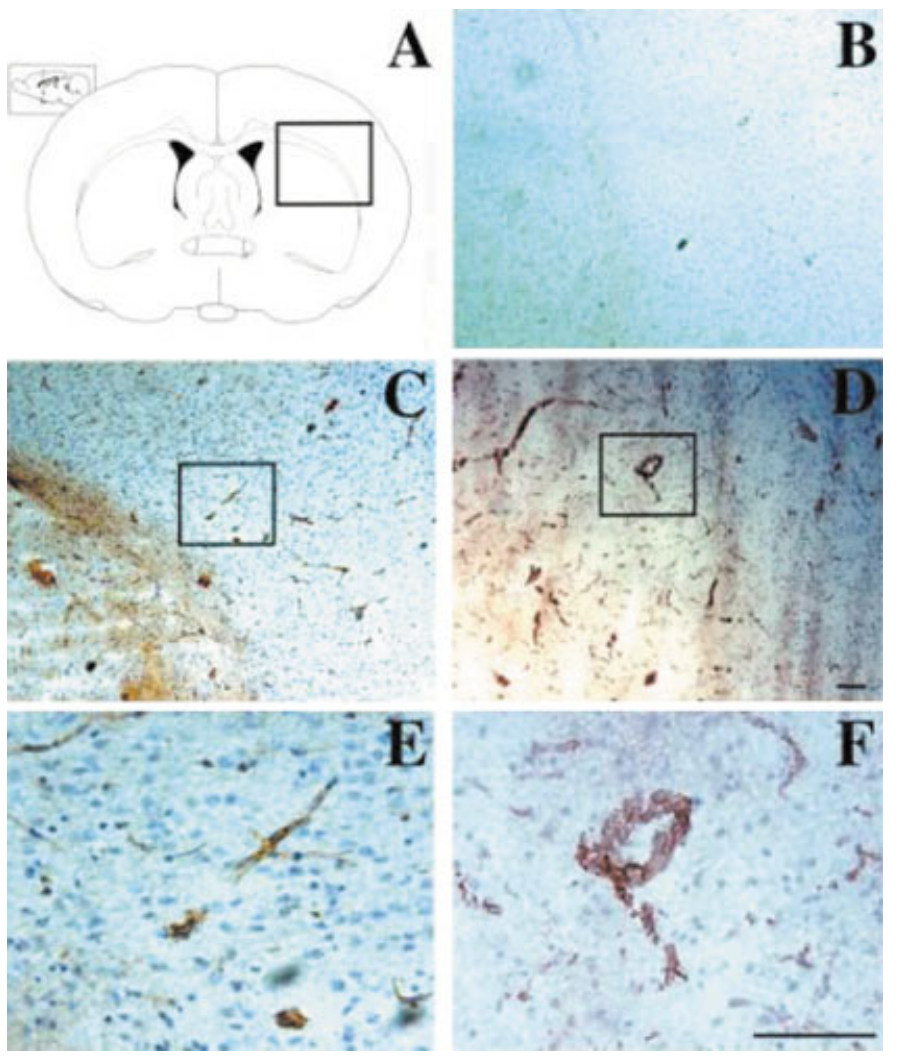

Figure 6.

was significantly decreased. The negative control section showed no ICAM-1-positive staining (data not shown). Few ICAM-1-positive vessels were detected in the ischemic hemisphere after $24 \mathrm{hr}$ of $\mathrm{MCAO}$ in the sham animals. 


\section{DISCUSSION}

This study demonstrates that the NFKB is phosphorylated in WT mice at the early stage of focal cerebral ischemia. This early NFKB phosphorylation is localized in neurons in the ischemic core and perifocal regions; however, NFкB phosphorylation is greatly reduced in ICE KO mice. Reduced ICAM-1 production, a NFKB target gene protein in the ICE KO mice, may be due to the reduction of NFKB phosphorylation. These findings suggest that the mature IL-1 $\beta$ and ICE genes may be important mediators of NFKB phosphorylation during early ischemia. Considerable evidence points to ICAM-1 as crucial mediator of ischemic brain damage. Thus, reduction of early NFKB phosphorylation may be one of the mechanisms through which ICE KO mice are protected from damaging inflammatory responses during focal cerebral ischemia.

Gene knockout mice provide useful tools for defining signaling pathways leading to ischemia-induced neuronal death (Huang et al., 1994; Yang et al., 1994). In a previous study, we demonstrated that after permanent focal ischemia, ICE KO mice had less brain edema and smaller infarction compared to WT controls (Schielke et al., 1998). A possible mechanism underlying this observation is reduced mature IL- $1 \beta$ production by the ischemic brain. ICE is a member of the caspase family of cysteine proteases, which are associated with both proinflammatory and apoptotic actions (Dinarello, 1992, 1996; Hara et al., 1997a;Yang et al., 1999a). ICE is critical for processing pro-IL-1 to the biologically active form of the cytokine, IL-1 $\beta$. Previous studies have demonstrated that macrophages isolated from the ICE KO mice are not capable of producing IL-1 $\beta$. Similarly, in a model of endotoxic shock, no IL- $1 \beta$ is detected in the plasma of the ICE KO mice, and survival is greatly enhanced. Interestingly, IL- $1 \alpha$ production is reduced also in these mice, although not to the extent of IL-1 $\beta$ (Dinarello, 1997a). The possibility of differences, however, in the genetic background of the knockout mice and their wild-type controls is a limitation in the use of gene knockout models. The ICE KO and WT mice used in this study were derived from the same progenitors, a mixed SV/129 and C57BL/6 background. Previous observations found that these ICE KO and WT mice developed normally (Schielke et al., 1998). Additionally, our data demonstrated that the changes in physiological parameters, cortical cerebral blood flow and body temperature, in response to MCAO, were similar in the two groups. Thus, the resistance to ischemia induced brain damage and activation of the NFKB pathways in the ICE $\mathrm{KO}$ mice is likely due to deletion of the ICE gene and not the differences in the genetic background of the $\mathrm{KO}$ and WT mice.

NFKB phosphorylation has been associated with immune and inflammatory responses. It is activated by a variety of stimuli known to occur in focal ischemia, such as cytokines, ROS, and glutamate (Baeuerle and Henkel, 1994). Expression of NFKB has been described in a variety of brain cell types, such as murine primary astrocytes, microglia, Schwann cells, neurons, and human endothelial cells (O'Neill and Kaltschmidt, 1997; Howard et al., 1998). NFкB activates the transcription of many genes thought to be involved in the pathogenesis of cerebral ischemia, including IL-1 $\beta$, TNF $\alpha$, iNOS, VCAM, ICAM-1, and IL-6. Thus, as a signaling molecule, NFKB may play a central role in the regulation of inflammatory responses to brain injury and infection. Existing evidence supports this concept. For example, Salminen et al. (1995) reported that $\mathrm{NF \kappa B}$ was increased significantly in the
Fig. 3. Activation of $\mathrm{p} 65 / \mathrm{NF \kappa B}$ in both cytoplasm and nucleus. $\mathrm{Mi}-$ crophotographs showing DAB-positive staining for phospho-p65/ NFKB in the mouse brain after $2(\mathbf{C})$ and $4 \mathrm{hr}(\mathbf{D})$ of MCAO. Arrows indicated no active p65/NFKB-positive cells were observed in the sham animal (A). Active p65/NFkB-positive staining could be observed after $2 \mathrm{hr}$ of MCAO and these cells displayed neuronal morphology (B; arrow indicates neuronal cell body and axons). Active p65/NFKBpositive staining located in cytoplasm after $2 \mathrm{hr}$ of MCAO in the WT mice $(\mathrm{C})$, and active $\mathrm{p} 65 / \mathrm{NF}$ B B-positive staining translocated into the nucleus after $4 \mathrm{hr}$ of MCAO in the WT mice (D). This result demonstrates that early p65 phosphorylation and translocation occurs in the ischemic cells. Scale bar $=20 \mu \mathrm{m}$.

Fig. 4. Activation of p65/NFkB in neurons. Double-labeling fluorescence photomicrographs from the ipsilateral cortex showing doublelabeled staining for p65/NFkB (green; A,D) and NSE (red; B,E); p65/NFkB was well colocalized with NSE staining, demonstrating that neurons express $\mathrm{p} 65 / \mathrm{NF \kappa B}$ after $\mathrm{MCAO}(\mathbf{C}, \mathbf{F})$. Neurons that are p65/NFkB-positive are detected in both ischemic cortex (A,B) and caudate putamen $(\mathrm{D}, \mathrm{E})$. Injured neurons in the ischemic hemisphere after $2 \mathrm{hr}$ of MCAO displayed strong active p65/NFKB immunoreactivity, indicating that the early NFKB activation occurs in the neuronal cells after ischemic insult. Arrows point to injured cells, showing shrunken cell bodies. Scale bar $=10 \mu \mathrm{m}$.
Fig. 5. DNA binding of NFKB after MCAO. Nuclear extraction and electrophoretic mobility shift assay (EMSA) of nuclear protein extracts from ischemic brain tissue, probed with ${ }^{32} \mathrm{P}$, labeled the doublestranded oligonucleotide containing the NFKB-specific binding sequence (5'-AGT TGA GGG GAC TTT CCC AGG C-3'). NFкB binding reactions were carried out in a final volume of $20 \mu$ l mixture containing buffer, $10 \mu \mathrm{g}$ nuclear proteins, and $10^{6} \mathrm{cpm}$ of radiolabeled probe. NFKB indicates the bands of specific DNA-protein complexes. The binding corresponding to active NFKB is detected in both the ICE $\mathrm{KO}$ and the WT mice after $0.5,2,4,8$, and $24 \mathrm{hr}$ of MCAO. This binding is largely reduced after 4,8 , and $24 \mathrm{hr}$ of MCAO in ICE KO mice compared to WT mice. C, positive control.

Fig. 6. Attenuation of ICAM-1 expression in ICE KO mice. Photographs showing ICAM-1-positive vessel staining in the ischemic perifocal areas in ICE KO $(\mathbf{C}, \mathbf{E})$ and the WT $(\mathbf{D}, \mathbf{F})$ mice after $24 \mathrm{hr}$ of MCAO. (A) shows the area examined, and (B) shows there are no ICAM-1-positive vessels in the negative control section (blocking peptide) after MCAO. The brown staining demonstrated that the expression of ICAM-1-positive vessels increased greatly after $24 \mathrm{hr}$ of MCAO in WT mice (D) compared to ICE KO mice (C). Magnification of squared areas in $\mathrm{C}$ and $\mathrm{D}$ are shown $(\mathrm{E}, \mathrm{F})$. Scale bar $=30 \mu \mathrm{m}$. 
ischemic cortex and hippocampus after $30 \mathrm{~min}$ of fourvessel occlusion and $72 \mathrm{hr}$ of reperfusion in rats. Yang et al. (1995) confirmed that NFKB expression was increased in the ipsilateral cortex in the rat brain trauma model, which is related to the production of IL-1 $\beta$ and TNF $\alpha$; however, Schneider et al. (1999) reported contradictory results: they found that infarct volume after $2 \mathrm{hr}$ of ischemia and $20 \mathrm{hr}$ of reperfusion was reduced significantly in the NFкB/p50 knockout mice $\left(42\right.$ vs. $\left.32 \mathrm{~mm}^{3}\right)$. There are several studies that demonstrate that NFKB phosphorylation provided neuroprotection in vitro (Blatteis, 1988). All these results suggest that NFKB phosphorylation plays different roles and transfers different signaling during focal cerebral ischemia. Depending upon the severity and duration of ischemia, NFKB could transfer neuroprotective or neurotoxic genes. These genes will then produce downstream proteins that will repair or further damage tissue.

Our data demonstrates that NFKB is phosphorylated after $2 \mathrm{hr}$ of MCAO in the WT mice, and this phosphoNFKB form is located mainly in neurons in the ischemic core and the perifocal regions. Reduction of the NFKB signal in the ischemic ICE KO mice suggests that early processing of pro-IL-1 to its active form may be a critical trigger for this response. We observed that cytosolic NFKB could translocate into the nucleus after $4 \mathrm{hr}$ of MCAO, and this is followed by an increase of nuclear NFKB DNA-binding activity. Because NFKB phosphorylation occurs earlier than the overexpression of cytokines (Bruce-Keller and Mattson, 1998), NFkB phosphorylation and translocation during MCAO may be the pathway by which an extracellular signal rapidly evokes a transcriptional response. Thus, as a signal molecule, NFкB may play a central role in the regulation of many inflammatory responses during brain injury.

ICAM-1, one of the most studied adhesion molecules, is located on the endothelial surface. Its leukocyte counterpart, integrin CD11/CD18, and many others are currently under investigation (Zhang et al., 1995; Yang et al., 1998). A number of experimental studies have documented that E-selectin (ELAM) and P-selectin are upregulated after focal cerebral ischemia in rodents (Okada et al., 1994; Wang et al., 1994, 1995; Jander et al., 1995; Zhang et al., 1995, 1996). There is considerable evidence supporting the idea that leukocyte infiltration into the brain contributes to the development of ischemic lesions. Blocking ICAM-1 with an antibody reduces both neutrophil accumulation and the size of the lesion (Zhang et al., 1994). The possible relevance of adhesion molecules in the pathogenesis of ischemic brain damage has been demonstrated recently, and mice deficient in the ICAM-1 gene show a marked reduction in cerebral infarction lesions after tMCAO (Connolly et al., 1996; Soriano et al., 1996). ICAM-1 expression is greatly increased in hypoxic endothelial cells in the presence of circulating endotoxin; however, pretreatment with salicylate, a novel NFкB inhibitor, completely abolishes the enhanced ICAM-1 expression (Zund et al., 1998). This study supports that salicylate administered before cardiopulmonary bypass may protect the heart against ischemia/reperfusion injuries and reduce the load of the overall inflammatory response (Zund et al., 1998). Proinflammatory cytokines IL-1 $\beta$ and TNF $\alpha$ are known to be induced earlier than the adhesion molecules (Wang and Feuerstein, 1995). IL-1 $\beta$ and TNF $\alpha$ can upregulate the expression of ICAM-1, ELAM-1, and P-selectin in vitro (Feuerstein et al., 1997; Yang et al., 1999a,b). The development of the inflammatory response in focal ischemia, therefore, may appear in the following sequence: expression of IL- $1 \beta$ and TNF $\alpha$, upregulation of adhesion molecules, and then migration of leukocytes. In our study, however, the expression of ICAM-1 protein is significantly lower in ICE KO mice compared to that in WT mice after MCAO. This result suggests that mature IL-1 $\beta$ is a critical mediator in the upregulation of ICAM-1 expression during cerebral ischemia.

In summary, we have demonstrated that $\mathrm{NF \kappa B}$ is phosphorylated and translocated to the nucleus after permanent MCAO in WT mice but significantly reduced in ICE KO mice, suggesting that NFKB phosphorylation and translocation during focal cerebral ischemia may depend partially on the existence of mature IL- $1 \beta$ or ICE. Compared to WT mice, in the ICE KO mice, ICAM-1 protein expression during permanent $\mathrm{MCAO}$ was reduced significantly, suggesting that NFKB may play an important role in control and regulation of downstream genes including the adhesion molecule ICAM-1. Because ICE is a member of a cysteine protease family that has been implicated in apoptotic cell death (Yuan et al., 1993), a yet to be answered question is whether these deleterious effects are mediated by IL- $1 \beta$ production or by pro-apoptotic mechanisms.

\section{ACKNOWLEDGMENT}

This work was supported by the National Institutes of Health (R01 NS-35089 to GYY).

\section{REFERENCES}

Arvin B, Neville LF, Barone FC, Feuerstein GZ. 1996. The role of inflammation and cytokines in brain injury. Neurosci Biobehav Rev 20:445-452.

Baeuerle PA, Baichwal VR. 1997. NF- $\mathrm{kB}$ as a frequent target for immunosuppressive and anti-inflammatory molecules. Adv Immunol 65:111-137.

Baeuerle PA, Henkel T. 1994. Function and activation of NF-кB in the immune system. Ann Rev Immunol 12:141-179.

Betz AL, Yang GY, Davidson BL. 1995. Attenuation of stroke size in rats using an adenoviral vector to induce overexpression of interleukin-1 receptor antagonist in brain. J Cereb Blood Flow Metab 15:547-551.

Blatteis CM. 1988. Neuronal mechanisms in the pyrogenic and acute phase responses to interleukin-1. Int J Neurosci 38:223-232.

Bruce-Keller AJ, Mattson MP. 1998. Modulatory role of NFкB in neuronal and glial responses to injury. In: Krieglstein J, editor. Pharmacology of cerebral ischemia. Stuttgart, Germany: Medpharma Scientific Publishers. p 309-317.

Carroll JE, Hess DC, Howard EF, Hill WD. 2000. Is nuclear factor-кB a good treatment target in brain ischemia/reperfusion injury? Neuroreport 11:1-4. 
Connolly ES Jr, Winfree CJ, Springer TA, Naka Y, Liao H, Yan SD, Stern DM, Solomon RA, Gutierrez-Ramos JC, Pinsky DJ. 1996. Cerebral protection in homozygous null ICAM-1 mice after middle cerebral artery occlusion. Role of neutrophil adhesion in the pathogenesis of stroke. J Clin Invest 97:209-216.

Dinarello CA. 1992. The biology of interleukin-1. In: Kishimoto T, editor. Interleukins: molecular biology and immunology. Basel, Switzerland: Karger. p 1-32.

Dinarello CA. 1996. Biologic basis for interleukin-1 in disease. Blood 87:2095-2147.

Dinarello CA. 1997a. Induction of interleukin-1 and interleukin-1 receptor antagonist. Semin Oncol 24:9-93.

Dinarello CA. 1997b. Proinflammatory and anti-inflammatory cytokines as mediators in the pathogenesis of septic shock. Chest 112:321-329.

Feuerstein GZ, Wang X, Barone FC. 1997. Inflammatory gene expression in cerebral ischemia and trauma. Potential new therapeutic targets. Ann N Y Acad Sci 825:179-193.

Gilmore TD. 1997. Clinically relevant findings. J Clin Invest 100:29352936.

Gilmore TD, Koedood M, Piffat KA, White DW. 1996. Rel/NF-кB/ІкB proteins and cancer. Oncogene 13:1367-1378.

Gong C, Qin Z, Betz AL, Liu XH, Yang GY. 1998. Cellular localization of tumor necrosis factor alpha following focal cerebral ischemia in mice. Brain Res 801:1-8.

Hara H, Fink K, Endres M, Friedlander RM, Gagliardini V, Yuan J, Moskowitz MA. 1997a. Attenuation of transient focal cerebral ischemic injury in transgenic mice expressing a mutant ICE inhibitory protein. J Cereb Blood Flow Metab 17:370-375.

Hara H, Friedlander RM, Gagliardini V, Ayata C, Fink K, Huang Z, Shimizu-Sasamata M, Yuan J, Moskowitz MA. 1997b. Inhibition of interleukin $1 \beta$ converting enzyme family proteases reduces ischemic and excitotoxic neuronal damage. Proc Natl Acad Sci USA 94:2007-2012.

Howard EF, Chen Q, Cheng C, Carroll JE, Hess D. 1998. NF-кB is activated and ICAM-1 gene expression is upregulated during reoxygenation of human brain endothelial cells. Neurosci Lett 248:199-203.

Huang Z, Huang PL, Panahian N, Dalkara T, Fishman MC, Moskowitz MA. 1994. Effects of cerebral ischemia in mice deficient in neuronal nitric oxide synthase. Science 265:1883-1885.

Jander S, Kraemer M, Schroeter M, Witte OW, Stoll G. 1995. Lymphocytic infiltration and expression of intercellular adhesion molecule-1 in photochemically induced ischemia of the rat cortex. J Cereb Blood Flow Metab 15:42-51.

Li P, Allen H, Banerjee S, Franklin S, Herzog L, Johnston C, McDowell J, Paskind M, Rodman L, Salfeld J. 1995. Mice deficient in IL-1 $\beta$-converting enzyme are defective in production of mature IL-1 $\beta$ and resistant to endotoxic shock. Cell 80:401-411.

Linnik MD, Zobrist RH, Hatfield MD. 1993. Evidence supporting a role for programmed cell death in focal cerebral ischemia in rats. Stroke 24:2002-2008.

Loddick SA, Rothwell NJ. 1996. Neuroprotective effects of human recombinant interleukin-1 receptor antagonist in focal cerebral ischemia in the rat. J Cereb Blood Flow Metab 16:932-940.

Mattson MP. 1997. Neuroprotective signal transduction: relevance to stroke. Neurosci Biobehav Rev 21:193-206.

Minami M, Kuraishi Y, Yabuuchi K, Yamazaki A, Satoh M. 1992. Induction of interleukin-1 $\beta$ mRNA in rat brain after transient forebrain ischemia. J Neurochem 58:390-392.

O'Neill LA, Kaltschmidt C. 1997. NF-кB: a crucial transcription factor for glial and neuronal cell function. Trends Neurosci 20:252-258.

Okada Y, Copeland BR, Mori E, Tung MM, Thomas WS, del Zoppo GJ. 1994. P-selectin and intercellular adhesion molecule-1 expression after focal brain ischemia and reperfusion. Stroke 25:202-211.

Rothwell NJ, Hopkins SJ. 1995. Cytokines and the nervous system II: actions and mechanisms of action. Trends Neurosci 18:130-136.
Salminen A, Liu PK, Hsu CY. 1995. Alteration of transcription factor binding activities in the ischemic rat brain. Biochem Biophys Res Comm 212:939-944.

Sambrook J, Fritsch EF, Maniatis T. 1989. Detection and analysis of proteins expressed from cloned genes. In: Ford N, editor. Molecular cloning: a laboratory manual. Vol. 3. 2nd Ed. New York: Cold Spring Harbor Laboratory Press. p 18.12-18.86.

Schielke GP, Yang GY, Shivers BD, Betz AL. 1998. Reduced ischemic brain injury in interleukin-1 $\beta$ converting enzyme-deficient mice. J Cereb Blood Flow Metab 18:180-185.

Schneider A, Martin-Villalba A, Weih F, Vogel J, Wirth T, Schwaninger M. 1999. NF-кB is activated and promotes cell death in focal cerebral ischemia. Nat Med 5:554-559.

Siebenlist U, Franzoso G, Brown K. 1994. Structure, regulation and function of NF-кB. Annu Rev Cell Biol 10:405-455.

Soriano SG, Lipton SA, Wang YF, Xiao M, Springer TA, GutierrezRamos JC, Hickey PR. 1996. Intercellular adhesion molecule-1-deficient mice are less susceptible to cerebral ischemia-reperfusion injury. Ann Neurol 39:618-624.

Szaflarski JS, Burtrum D, Silverstein FS. 1995. Cerebral hypoxia-ischemia stimulates cytokine gene expression in perinatal rats. Stroke 26:10931100.

Verma IM, Stevenson JK, Schwarz EM, Van Antwerp D, Miyamoto S. 1995. Rel/NF-кB/IкB family: intimate tales of association and dissociation. Genes Dev 9:2723-2735.

Wang X, Feuerstein GZ. 1995. Induced expression of adhesion molecules following focal brain ischemia. J Neurotrauma 12:825-832.

Wang X, Siren AL, Liu Y, Yue TL, Barone FC, Feuerstein GZ. 1994. Upregulation of intercellular adhesion molecule 1 (ICAM-1) on brain microvascular endothelial cells in rat ischemic cortex. Brain Res Mol Brain Res 26:61-68.

Wang XK, Yue T-L, Barone FC, Feuerstein GZ. 1995. Demonstration of increased endothelial-leukocyte adhesion molecule-1 mRNA expression in rat ischemic cortex. Stroke 26:1665-1669.

Yamasaki Y, Itoyama Y, Kogure K. 1996. Involvement of cytokine production in pathogenesis of transient cerebral ischemic damage. Keio J Med 45:225-229.

Yamasaki Y, Suzuki T, Yamaya H, Matsuura N, Onodera H, Kogure K. 1992. Possible involvement of interleukin-1 in ischemic brain edema formation. Neurosci Lett 142:45-47.

Yang GY, Chan PH, Chen J, Carlson E, Chen SF, Weinstein P, Epstein CJ, Kamii H. 1994. Human copper-zinc superoxide dismutase transgenic mice are highly resistant to reperfusion injury after focal cerebral ischemia. Stroke 25:165-170.

Yang GY, Liu XH, Kadoya C, Zhao YJ, Betz AL. 1998. Attenuation of ischemic inflammatory response in mouse brain using an adenoviral vector to induce overexpression of interleukin-1 receptor antagonist. J Cereb Blood Flow Metab 18:840-847.

Yang GY, Mao Y, Zhou LF, Gong C, Ge HL, Betz AL. 1999a. Expression of intercellular adhesion molecule 1 (ICAM-1) is reduced in permanent focal cerebral ischemic mouse brain using an adenoviral vector to induce overexpression of interleukin-1 receptor antagonist. Brain Res Mol Brain Res 65:143-150.

Yang GY, Mao Y, Zhou LF, Ye W, Liu XH, Gong C, Betz AL. 1999b. Attenuation of temporary focal cerebral ischemic injury in the mouse following transfection with interleukin-1 receptor antagonist. Brain Res Mol Brain Res 72:129-137.

Yang GY, Schielke GP, Gong C, Mao Y, Ge HL, Liu XH, Betz AL. 1999c. Expression of tumor necrosis factor-alpha and intercellular adhesion molecule-1 after focal cerebral ischemia in interleukin-1beta converting enzyme deficient mice. J Cereb Blood Flow Metab 19:1109-1117.

Yang GY, Zhao Y, Davidson BL, Betz AL. 1997. Overexpression of interleukin-1 receptor antagonist in the mouse brain reduces ischemic brain injury. Brain Res 751:181-188. 
Yang K, Mu XS, Hayes RL. 1995. Increased cortical nuclear factor-kappa $\mathrm{B}(\mathrm{NF}-\kappa \mathrm{B})$ DNA binding activity after traumatic brain injury in rats. Neurosci Lett 197:101-104.

Yuan J, Shaham S, Ledoux S, Ellis HM, Horvitz HR. 1993. The C. elegans cell death gene ced-3 encodes a protein similar to mammalian interleukin-1 beta-converting enzyme. Cell 75:641-652.

Zhang RL, Chopp M, Li Y, Zaloga C, Jiang N, Jones ML, Miyasaka M, Ward P. 1994. Anti-ICAM-1 antibody reduces ischemic cell damage after transient middle cerebral artery occlusion in the rat. Neurology 44:1747-1751.

Zhang RL, Chopp M, Zaloga C, Zhang ZG, Jiang N, Gautam SC, Tang
WX, Tsang W, Anderson DC, Manning AM. 1995. The temporal profiles of ICAM-1 protein and mRNA expression after transient MCA occlusion in the rat. Brain Res 682:182-188.

Zhang RL, Chopp M, Zhang ZG, Phillips ML, Rosenbloom CL, Cruz R, Manning A. 1996. E-selectin in focal cerebral ischemia and reperfusion in the rat. J Cereb Blood Flow Metab 16:1126-1136.

Zund G, Dzus AL, Pretre R, Niederhauser U, Vogt P, Turina M. 1998. Endothelial cell injury in cardiac surgery: salicylate may be protective by reducing expression of endothelial adhesion molecules. Eur J Cardiothorac Surg 13:293-297. 